\title{
Risiko Penyakit Kulit Akibat Kerja di Perusahaan Perkebunan dan Pengolahan Karet
}

\author{
Mei Ahyanti ${ }^{1}$, Purwono ${ }^{2}$ \\ ${ }^{1,2}$ Jurusan Kesehatan Lingkungan, Politeknik Kesehatan Tanjungkarang, Indonesia \\ Email: mei.ahyanti@gmail.com
}

\begin{abstract}
Risk of Skin Disease Due to Work in Plantation Companies and Rubber Processing. Skin disease is a disease that attacks the body's surface and is caused by a variety of causes. PTPN VII Business Unit Way Berulu Regency Pesawaran, Lampung company plantation, and rubber/ latex. The length of time required in the processing and the addition of chemical substances at risk against the workers. The research aims to know the risk factors of occupational skin disease occurrences in PTPN VII Business Unit Berulu Way, using design case control with the total sample as many as 73 cases and 73 controls so that the total sample is 146 people, held on June-October 2017. The determination of cases based on Medical Records that are in the health service center of the plantation (Puskesbun). The analysis is done in univariate, and bivariate using Chi-Square test. The results of the analysis concluded that there was a significant relationship between previous skin disease history ( $\mathrm{pv}=0,000, \mathrm{OR}=4,399,95 \% \mathrm{CI}=1,995-9,698)$, personal hygiene $(\mathrm{pv}=0,000, \mathrm{OR}=4,100,95 \% \mathrm{CI}=1,953-8,608)$, supply of clean water ( $\mathrm{pv}=0.020$, $\mathrm{OR}=2.304,95 \% \mathrm{CI}=1.187-4.472)$ and use of APD ( $\mathrm{pv}=0.037, \mathrm{OR}=2.177,95 \% \mathrm{CI}=1.123-4.220)$ with the incidence of skin diseases due to work.
\end{abstract}

Keywords: Latex, Personal hygiene, PTPN VII, Skin disease

\begin{abstract}
Abstrak: Risiko Penyakit Kulit Akibat Kerja di Perusahaan Perkebunan dan Pengolahan Karet. Penyakit kulit merupakan suatu penyakit yang menyerang permukaan tubuh, dan disebabkan oleh berbagai macam penyebab. PTPN VII Unit Usaha Way Berulu Kabupaten Pesawaran, Lampung merupakan perusahaan perkebunan dan pengolahan karet/latek. Lamanya waktu yang diperlukan dalam pengolahan dan penambahan zat kimia berisiko terhadap pekerja. Penelitian bertujuan mengetahui faktor risiko kejadian penyakit kulit akibat kerja di PTPN VII Unit Usaha Way Berulu, menggunakan desain case control dengan jumlah sampel sebanyak 73 kasus dan 73 kontrol sehingga total sampel adalah 146 orang, dilaksanakan pada bulan JuniOktober 2017. Penentuan kasus berdasarkan Medical Record yang ada di Pusat Pelayanan Kesehatan Perkebunan (Puskesbun). Analisis dilakukan secara univariat, dan bivariat menggunakan uji Chi Square. Hasil analisis menyimpulkan terdapat hubungan yang bermakna antara riwayat penyakit kulit sebelumnya $(p=0,000, \mathrm{OR}=4,399$, CI 95\%=1,995-9,698), personal hygiene $(p=0,000, \mathrm{OR}=4,100, \mathrm{CI} 95 \%=1,953-8,608)$, penyediaan air bersih $(p=0,020, \mathrm{OR}=2,304$, CI 95\%=1,187-4,472) dan penggunaan APD ( $p=0,037$, OR=2,177, CI 95\%=1,123-4,220) dengan kejadian penyakit kulit akibat kerja.
\end{abstract}

Kata kunci: Latek, Personal hygiene, PTPN VII, Penyakit kulit

\section{PENDAHULUAN}

Peningkatan perkembangan industri dan perubahan global di bidang pembangunan secara umum di dunia, menyebabkan Indonesia melakukan banyak perubahan dalam pembangunan, baik bidang teknologi maupun industri. Perubahan tersebut, memberikan konseksuensi terhadap terjadinya perubahan pola penyakit/kasus penyakit karena hubungan dengan pekerjaan (Nuraga, et al, 2008).

Di Uni Eropa penyakit kulit menduduki peringkat kedua penyakit akibat kerja (PAK) setelah gangguan muskuloskeletal. Dermatitis kontak mencapai $70-90 \%$ dari semua penyakit kulit akibat kerja, sedangkan urtikaria hanya sekitar $10 \%$. Gangguan kulit lainnya termasuk folikulitis, akne, neoplasia, hiperpigmentasi dan vitiligo (Adisesh A et al, 2013). Dermatitis kontak adalah suatu reaksi peradangan akibat kontak kulit dengan suatu bahan. Dermatitis disertai dengan adanya spongiosis atau edema interseluler pada epidermis karena kulit berinteraksi dengan bahan-bahan kimia yang terpajan dengan kulit (Stateschu, 2011). 
Menurut hasil surveilans di Amerika, ini adalah masalah umum yang dihadapi di klinik dermatologi. Dari semua kasus dermatitis kontak, $80 \%$ disebabkan oleh dermatitis kontak iritan dan $20 \%$ disebabkan oleh dermatitis kontak alergi (Nelson, 2010). Hasil tersebut dipertegas oleh Usatine \& Riojas (2010) bahwa angka tertinggi kasus dermatitis tersebut pada pekerja perkebunan, industri manufaktur dan pekerja di bidang kesehatan.

Indonesia termasuk dalam negara berkembang, mayoritas penduduknya bekerja pada sektor pertanian dan perkebunan. Pada studi epidemiologi di Indonesia, data menunjukkan bahwa 97\% dari 389 kasus adalah dermatitis kontak, dimana 66,3\% diantaranya adalah DKI dan 33,7\% adalah DKA (Hudyono, 2002). Provinsi Lampung merupakan daerah agroindustri, salah satu perusahaan pengolah karet yang terkenal adalah PTPN VII Unit Usaha Way Berulu. Koagulasi secara manual menggunakan bantuan kaki dan tangan saat menginjak dan memadatkan latek serta air yang dialirkan secara terus menerus dan lamanya waktu yang diperlukan dalam proses produksi dapat berisiko terhadap pekerja berupa terjadinya penyakit kulit akibat kerja disebabkan oleh lingkungan maupun personal hygiene yang tidak baik saat melakukan pekerjaan. Upaya pengobatan dan pengendalian sudah dilakukan, namun prevalensi penyakit kulit masih tinggi. Menurut laporan petugas Puskesmas Kebun (Puskesbun) PT. PTPN VII Unit Usaha Way Berulu, pada tahun 2015 penderitanya sebanyak 108 pekerja, sedangkan tahun 2016 sebanyak 164 orang menderita penyakit kulit dengan 63 kasus baru.

Beberapa penelitian pada bidang pertanian dan perkebunan memperoleh hasil adanya hubungan yang bermakna antara riwayat penyakit kulit sebelumnya, personal hygiene dan penggunaan APD dengan dermatitis kontak. Dari data tersebut, diperlukan suatu penelitian tentang faktor risiko kejadian penyakit kulit akibat kerja untuk menekan tingginya angka kesakitan yang ditimbulkan.

\section{METODE}

Penelitian observasional dengan rancangan Case Control ini menggunakan sampel pekerja bagian tanaman perkebunan dan pengolahan PTPN VII sebanyak 146 pekerja terdiri dari 73 kasus dan 73 kontrol. Sampel dihitung menggunakan rumus besar sampel estimasi ratio odds (Ariawan, 1998). Kasus yang dipilih adalah kasus baru pada tahun 2017 yang Menderita penyakit kulit secara klinis oleh dokter dan konfirmasi laboratorik berdasarkan Medical Record yang ada di Puskesbun PTPN VII. Untuk menghindari bias pada penelitian ini, maka untuk memilih sampel kontrol dengan matching terhadap usia dan lama kerja. Kriteria sampel sebagai berikut :

a. Kriteria inklusi kasus.

1) Karyawan bagian perkebunan dan pengolahan karet di PTPN VII Unit Usaha Way Berulu

2) Berusia 20-55 tahun

3) Memiliki lama kerja $>2$ tahun

b. Kriteria eksklusi kasus

1) Tidak bersedia menjadi responden

2) Telah pindah kerja, pensiun atau meninggal

3) Sudah 3 kali didatangi untuk diwawancarai tetapi tidak ada

Data dikumpulkan melalui wawancara dengan pekerja. Pekerja yang bersedia menjadi responden diminta untuk menandatangani etical crearence. Selanjutnya data diolah menggunakan program statistik komputer dan dianalisa menggunakan uji chi-square.

\section{HASIL}

Tabel 1 menggambarkan faktor risiko pekerja terhadap penyakit kulit. Pekerja yang pernah menderita penyakit kulit sebelumnya adalah sebesar $29,5 \%$. Bentuk kelainan yang paling banyak diderita adalah gatal, kemerahan dan kulit kering serta kulit bersisik, sedangkan bagian tubuh yang paling banyak menderita sakit adalah telapak tangan, lengan tangan, kaki, leher, punggung dan sela-sela jari. Sebesar 34,2\% pekerja memiliki personal hygiene yang kurang baik. Penilaian terhadap personal hygiene dilakukan berdasarkan kebersihan rambut dan kepala (kebiasaan mencuci rambut secara teratur, penggunaan alat pemeliharaan rambut, kondisi alat dan kebersihan kepala), kebersihan tangan, kaki dan kuku (waktu mencuci tangan, penggunaan sabun, cara mencuci tangan, kebersihan kuku dan selalu pendek, frekuensi memotong kuku), kebersihan kulit (frekuensi mandi, penggunaan alat mandi sendiri seperti sabun dan handuk, dan mengganti pakaian setiap hari). Penyediaan air bersih pada 48,6\% tidak memenuhi syarat kesehatan. Terdapat $47,9 \%$ pekerja tidak menggunakan APD sedangkan yang menggunakan APD hanya 52,1\%. 
Tabel 1. Distribusi Responden berdasarkan Faktor Risiko

\begin{tabular}{lrr}
\hline \multicolumn{1}{c}{ Faktor Risiko } & n & \% \\
\hline Riwayat Penyakit Kulit Sebelumnya & & \\
\hline Pernah menderita penyakit kulit & 43 & 29,5 \\
Tidak pernah menderita penyakit kulit & 103 & 70,5 \\
\hline Personal Hygiene & & \\
\hline Kurang Baik & 50 & 34,2 \\
Baik & 96 & 65,8 \\
\hline Penyediaan Air Bersih & & \\
\hline Tidak Memenuhi Syarat & 71 & 48,6 \\
Memenuhi Syarat & 75 & 51,4 \\
\hline Penggunaan APD & & \\
\hline Tidak Menggunakan & 70 & 47,9 \\
Menggunakan & 76 & 52,1 \\
\hline
\end{tabular}

Dari tabel 2 dapat dijelaskan pada kelompok pekerja penderita penyakit dan pernah menderita penyakit kulit sebelumnya adalah sebanyak $43,8 \%$, dan tidak pernah menderita penyakit kulit sebelumnya sebanyak 56,2\%. Pada kelompok pekerja yang bukan penderita penyakit kulit dan pernah menderita penyakit kulit sebelumnya sebanyak $15,1 \%$ dan dan tidak pernah menderita penyakit kulit sebelumnya sebanyak $84,9 \%$. Hasil uji statistik mendapatkan nilai $p=0,000<\alpha(0,050)$, $\mathrm{OR}=4,399$ (CI 95\%=1,995-9,698), yang artinya bahwa terdapat hubungn yang bermakna antara riwayat penyakit sebelumnya dengan kejadian penyakit kulit akibat kerja. Pekerja yang pernah menderita penyakit kulit sebelumnya mempunyai risiko 4,399 kali untuk menderita penyakit kulit akibat kerja dibandingkan dengan pekerja yang sebelumnya tidak pernah menderita penyakit kulit.

Pada kelompok pekerja penderita penyakit kulit yang memiliki personal hygiene kurang baik sebanyak 49,3\%, dan memiliki personal hygiene baik sebanyak 50,7 \%. Pada kelompok pekerja bukan penderita penyakit kulit dengan personal hygiene kurang baik sebanyak 19,2\%, dengan personal hygiene baik $80,8 \%$. Hasil uji statistik mendapatkan nilai $p=0,000 \quad \mathrm{OR}=4,100$ (CI 95\%=1,953-8,608). Hal ini dapat diartikan bahwa terdapat hubungan yang bermakna antara personal hygiene dengan kejadian penyakit kulit akibat kerja. Pekerja yang memiliki personal hygiene kurang baik, berisiko 4,100 kali untuk menderita penyakit kulita akibat kerja dibandingkan dengan pekerja yang memiliki personal hygiene baik.

Selanjutnya, pada kelompok pekerja penderita penyakit kulit yang penyediaan air bersih di rumahnya tidak memenuhi syarat sebanyak $58,9 \%$, dan memenuhi syarat sebanyak 41,4\%. Pada kelompok pekerja bukan penderita penyakit kulit yang penyediaan air bersih di rumahnya tidak memenuhi syarat sebanyak $38,4 \%$, dan memenuhi syarat sebanyak $61,56 \%$. Hasil uji statistik mendapatkan nilai $p=0,020$, OR 2,304 (CI 95\%=1,187-4,472). Hasil tersebut dapat diartikan bahwa terdapat hubungan yang bermakna antara penyediaan air bersih dengan kejadian penyakit kulit akibat kerja. Pekerja yang memiliki tempat penyediaan air bersih dirumahnya tidak memenuhi syarat berisiko 2,304 kali untuk menderita penyakit kulita akibat kerja dibandingkan dengan pekerja yang memiliki penyediaan air bersih memenuhi syarat.

Pada kelompok pekerja penderita penyakit kulit yang tidak menggunakan APD sebanyak 57,5\%, yang menggunakan APD baik sebanyak 42,5\%. Pada kelompok pekerja bukan penderita penyakit kulit yang tidak menggunakan APD sebanyak 38,4\%, dan yang menggunakan APD $61,6 \%$. Hasil uji statistik mendapatkan nilai $p=0,037, \mathrm{OR}=2,177$ (CI 95\%=1,123-4,220). Dari hasil tersebut dapat diartikan bahwa teradapat hubungan bermakna antara penggunaan APD dengan kejadian penyakit kulit akibat kerja. Pekerja yang tidak menggunakan APD berisiko 2,177 kali menderita penyakit kulit akibat kerja dibanding dengan pekerja yang menggunakan APD saat bekerja.

Tabel 2. Distribusi Responden Berdasarkan Faktor Risiko dengan Kejadian Penyakit Kulit

\begin{tabular}{|c|c|c|c|c|c|c|}
\hline \multirow{3}{*}{$\begin{array}{l}\text { Faktor } \\
\text { Risiko }\end{array}$} & \multicolumn{4}{|c|}{ Kejadian penyakit Kulit } & \multirow{3}{*}{$\begin{array}{c}p- \\
\text { value }\end{array}$} & \multirow{3}{*}{$\begin{array}{c}\text { OR } \\
\text { CI } 95 \%\end{array}$} \\
\hline & \multicolumn{2}{|c|}{ Kasus } & \multicolumn{2}{|c|}{ Kontrol } & & \\
\hline & $\mathbf{n}$ & $\%$ & $\mathbf{n}$ & $\%$ & & \\
\hline \multicolumn{7}{|c|}{ Riwayat Penyakit Kulit Sebelumnya } \\
\hline $\begin{array}{l}\text { Pernah } \\
\text { menderita }\end{array}$ & 32 & 43,8 & 11 & 15,1 & \multirow{2}{*}{0,000} & 4,399 \\
\hline $\begin{array}{l}\text { Tidak pernah } \\
\text { menderita }\end{array}$ & 41 & 56,2 & 62 & 84,9 & & $1,995-9,698$ \\
\hline \multicolumn{7}{|c|}{ Personal Hygiene } \\
\hline Kurang Baik & 36 & 49,3 & 14 & 19,2 & \multirow{2}{*}{0,000} & 4,100 \\
\hline Baik & 37 & 50,7 & 59 & 80,8 & & $1,953-8,608$ \\
\hline \multicolumn{7}{|c|}{ Penyediaan Air Bersih } \\
\hline $\mathrm{Tdk}$ & & & & & \multirow{4}{*}{0,020} & \\
\hline Memenuhi & 43 & 58,9 & 28 & 38,4 & & 2.304 \\
\hline Syarat & & & & & & $1,187-4,472$ \\
\hline $\begin{array}{l}\text { Memenuhi } \\
\text { Syarat }\end{array}$ & 30 & 41,1 & 45 & 61,6 & & \\
\hline \multicolumn{7}{|c|}{ Penggunaan APD } \\
\hline $\begin{array}{l}\text { Tidak } \\
\text { Menggunakan }\end{array}$ & 42 & 57,5 & 28 & 38,4 & \multirow[t]{2}{*}{0,037} & \multirow{2}{*}{$\begin{array}{r}2,177 \\
1,123-4,220\end{array}$} \\
\hline Menggunakan & 31 & 42,5 & 45 & 61,6 & & \\
\hline
\end{tabular}

\section{PEMBAHASAN}

\section{Riwayat Penyakit Kulit Sebelumnya}

Kulit merupakan bagian dari tubuh manusia yang paling sensitif terhadap serangan 
berbagai macam penyakit, karena kulit adalah sistem pertahanan terluar dari tubuh dan merupakan benteng penghalang bagi mikroorganisme yang akan menyerang tubuh. Menurut Wasitaatmadja (2011) ada hubungan yang bermakna antara riwayat penyakit kulit sebelumnya dengan kejadian penyakit kulit. Didapatkan nilai OR 4,399 yang artinya bahwa pekerja yang pernah menderita penyakit kulit sebelumnya berisiko sebesar 4,399 kali menderita penyakit kulit dibandingkan dengan pekerja yang tidak pernah menderita penyakit kulit sebelumnya.

Penyakit kulit bisa disebabkan oleh beberapa faktor, diantaranya faktor lingkungan dan kebiasaan sehari-hari dari pekerja. Kejadian penyakit kulit yang saat ini dialami dapat disebabkan karena sebelumnya pekerja pernah mengalami penyakit kulit dan terjadi kekambuhan karena adanya pencetus. Salah satu pencetusnya adalah paparan zat-zat kimia yang ditambahkan saat proses pengolahan karet yaitu amoniak dan asam semut. Pekerja menginjak dan memadatkan latek menggunakan tangan dan kaki secara langsung tanpa menggunakan pelindung pada beberapa kolam yang proses coagulatingnya tidak sempurna. Pengaliran air secara terus menerus saat proses pengolahan yang terjadi selama sepuluh jam mengharuskan juga pekerja bekerja di tempat yang basah dan terpapar zat-zat kimia.

Data di atas menunjukkan bahwa lingkungan yang sehat dan bersih akan membawa efek baik bagi kulit, demikian pula sebaliknya. Salah satu lingkungan yang perlu diperhatikan adalah lingkungan kerja, apabila tidak dijaga dengan baik dapat menjadi sumber munculnya berbagai macam penyakit kulit.

Penyakit kulit yang pekerja derita sebelumnya dapat menjadi salah satu faktor yang menyebabkan pekerja menderita dermatitis kontak kembali (riwayat berulang). Reaksi berlebihan terhadap bahan tertentu akan menjadi pemicu timbulnya kembali penyakit kulit yang pernah diderita sebelumnya yang kita sebut dengan alergi. Penelitian lain oleh Pratiwi (2016). juga memperoleh nilai $p=0,006$, menunjukkan bahwa terdapat hubungan yang signifikan antara riwayat penyakit sebelumnya.

Di Indonesia, umumnya pekerja telah bekerja pada lebih dari satu tempat kerja. Hal ini menyebabkan adanya kemungkinan bahwa pekerja yang telah mengalami dermatitis pada pekerjaan sebelumnya terbawa ke tempat kerja yang baru.

Melihat kenyataan yang ada, artinya penyakit kulit harus diobati hingga tuntas, karena penyakit kulit memiliki kecenderungan untuk menular baik kepada anggota keluarga maupun kepada orang lain. Jika tidak ditangani secara cepat dan benar akan memberikan dampak gangguan rasa nyaman/gatal yang berlarut-larut, semakin meningkatkan penularan kepada orang lain, jaringan kulit menjadi rusak sehingga akan berujung pada gangguan aktivitas sehari-hari dan mengganggu produktivitas kerja.

Pengobatan adalah langkah terakhir jika penyakit kulit sudah menyerang. Agar dapat terhindar dari penyakit kulit, tindakan pencegahan yang dapat dilakukan oleh pekerja adalah meningkatkan kebersihan diri, menghindari kontak langsung dengan penderita serta menghindari penggunaan perlengkapan pribadi secara bersamaan. Perlu adanya edukasi dari perusahaan melalui kegiatan penyuluhan dan pengabdian kepada masyarakat yang memberikan pemahaman tentang penyakit kulit, faktor risiko, pencegahan dan pengobatan sangat penting.

\section{Personal Hygiene}

Kulit merupakan bagian penting terluar yang berfungsi sebagai sistem pertahanan tubuh, untuk itu kesehatan kulit harus dijaga dan dirawat. Melalui kulit terlihat cerminan kesehatan yang pertama. Kulit harus dijaga dengan meningkatkan personal hygiene. Isro'in (2012) menyebutkan bahwa gangguan atau dampak yang dapat timbul akibat personal hygiene yang kurang yaitu dampak fisik dan dampak psikososial. Dampak fisik, adalah gangguan fisik yang terjadi karena adanya gangguan kesehatan yang diderita seseorang karena tidak terpeliharanya kebersihan perorangan dengan baik. Gangguan yang sering timbul yaitu gangguan membran mukosa mulut, gangguan integritas kulit, infeksi pada mata dan telinga, serta gangguan sisik pada kuku. Dampak psikososial, adalah masalah sosial yang berhubungan dengan personal hygiene, diantaranya gangguan kebutuhan rasa nyaman, gangguan interaksi sosial dan aktualisasi diri.

Sebanyak $34,2 \%$ telah memiliki personal hygiene yang baik dan $65,8 \%$ memiliki personal hygiene kurang baik. Artinya pekerja pada PTPN VII Unit usaha Way Berulu masih banyak yang belum menyadari bahwa hidup sehat melalui perawatan diri sangat penting.

Penilaian terhadap personal hygiene dilakukan berdasarkan kebersihan rambut dan kepala (kebiasaan mencuci rambut secara teratur, penggunaan alat pemeliharaan rambut, kondisi alat dan kebersihan kepala), kebersihan tangan, kaki dan kuku (waktu mencuci tangan, 
penggunaan sabun, cara mencuci tangan, kebersihan kuku dan selalu pendek, frekuensi memotong kuku), kebersihan kulit (frekuensi mandi, penggunaan alat mandi sendiri seperti sabun dan handuk, dan mengganti pakaian setiap hari).

Kebiasaan-kebiasaan yang sehat harus selalu diperhatikan dalam memelihara kebersihan kulit adalah menggunakan barang-barang keperluan untuk sehari-hari milik sendiri seperti sabun, handuk, sisir, sikat gigi, dan lain-lain. Mandi minimal 2 kali sehari, menggunakan sabun agar kotoran yang melekat pada tubuh dapat terdesinfeksi.

Menjaga kebersihan pakaian, selalu mengganti pakaian setiap hari, dan makan yang bergizi terutama banyak sayur dan buah, serta menjaga kebersihan lingkungan. Mencuci rambut sekurang-kurangnya 2 kali seminggu, memakai sampo/bahan pencuci rambut lainnya, dan sebaiknya menggunakan alat-alat pemeliharaan rambut sendiri merupakan upaya memelihara kebersihan rambut dan kulit kepala. Rambut yang terpelihara dengan baik akan membuat bersih dan indah sehingga menimbulkan kesan bersih dan tidak berbau.

Tangan, kaki, dan kuku yang bersih menghindarkan kita dari berbagai penyakit. Kuku dan tangan yang kotor dapat menyebabkan bahaya kontaminasi dan menimbulkan penyakitpenyakit berbahaya seperti diare, kecacingan juga penyakit kulit. Untuk menghindari bahaya kontaminasi maka harus membersihkan tangan sebelum makan, memotong kuku secara teratur, membersihkan lingkungan, dan mencuci kaki sebelum tidur.

Penelitian ini menemukan bahwa ada hubungan yang bermakna antara personal hygiene dengan kejadian penyakit kulit. Hasil uji statistik mendapatkan nilai $p=0,000<\alpha \quad(0,050)$ dengan nilai OR sebesar $=4,100$, artinya pekerja dengan personal hygiene kurang baik berisiko 4,100 kali menderita penyakit kulit akibat kerja dibanding dengan pekerja dengan personal hygiene baik. Selanjutnya pada tabel 2 digambarkan kelompok pekerja menderita penyakit kulit dengan personal hygiene kurang baik sebanyak 49,3\%, dengan personal hygiene baik sebanyak 50,7\%. Pada kelompok pekerja menderita penyakit kulit dengan personal hygiene kurang baik sebanyak 19,2\%, dengan personal hygiene baik $80,8 \%$.

Hasil tersebut sejalan dengan penelitian Hilma (2014) yang menyatakan ada hubungan bermakna antara tingkat hygienitas dengan penyakit kulit. Penelitian lain oleh Rahma, dkk (2017), menyatakan bahwa kecenderungan pekerja dengan personal hygiene yang buruk untuk terjadinya dermatitis akibat kerja adalah 3 kali lebih besar.

Kebiasaan baik yang sudah tertanam berkaitan dengan menjaga kebersihan diri harus dipertahankan, agar kesehatan selalu terjaga. Dan bagi pekerja yang belum menjaga kebersihan diri dengan maksimal, sebaiknya meningkatkan perilaku hidup bersih dan sehat, untuk menghidarkan diri dari penyakit menular seperti penyakit kulit.

Peran serta Puskesmas Kebun PTP dalam rangka menjaga dan meningkatkan kesehatan pekerja sangatlah penting. Pemeriksaan berkala yang telah dilaksanakan selama ini melalui kegiatan pengabdian kepada masyarakat hendaknya bukan hanya untuk penyakit-penyakit tidak menular seperti jantung dan gula darah saja, tetapi dapat juga pemeriksaan terhadap penyakit tidak menular contohnya penyakit kulit dan pengobatan secara dini terhadap gejala yang ditemui saat pemeriksaan berkala.

\section{Penyediaan Air Bersih}

Air merupakan komponen penting yang mutlak diperlukan oleh manusia. Tanpa air manusia tidak akan bisa hidup, karena sebagian besar dari tubuh manusia terdiri dari air. Namun air juga bisa membawa bahaya bagi manusia. Air bersih dan memenuhi syarat kesehatan merupakan unsur pokok yang harus dipenuhi agar manusia dapat mencapai hidup sehat.

Tabel 1 menggambarkan 51,4\% responden telah menyediakan air bersih yang memenuhi syarat, sedangkan $48,6 \%$ tidak memenuhi syarat. Data tersebut menunjukkan bahwa sebagian besar pekerja telah menyediakan air yang memenuhi syarat kesehatan dari sisi fisik dan mikrobiologi. Sumber air bersih yang digunakan oleh responden mayoritas berasal dari PAM PTP $(51,4 \%)$, sumur $(28,8 \%)$, PAM $(11,0 \%)$, mata air $(4,1 \%)$, sumur gali $(2,1 \%)$, sumur bor $(1,4 \%)$ dan sungai $(1,4 \%)$. Air bersih tersebut digunakan untuk keperluan sehari-hari seperti mandi, mencuci pakaian, memasak dan lain-lain.

Hasil penelitian diatas menyatakan sumber air yang digunakan oleh pekerja sebagian besar adalah sumber air yang baik. Namun saat dilakukan penampungan di rumah pekerja, banyak yang ditampung ditempat yang tidak tertutup, sehingga memungkinkan kontaminasi dari luar yang menyebabkan pengguna air tersebut dapat menderita penyakit salah satunya adalah penyakit kulit. Dari tabel 2 dapat dijelaskan bahwa pada kelompok pekerja yang menderita penyakit kulit, terdapat $58,9 \%$ pekerja 
yang dirumahnya memiliki penyediaan air bersih tidak memenuhi syarat, dan $41,4 \%$ memenuhi syarat. Pada kelompok pekerja yang menderita penyakit kulit yang penyediaan air bersihnya tidak memenuhi syarat sebanyak $38,4 \%$, dan memenuhi syarat sebanyak $61,56 \%$. Hasil uji statistik memperoleh nilai $p=0,020<\alpha \quad(0,050)$, maka disimpulkan ada hubungan yang bermakna antara riwayat penyakit kulit sebelumnya dengan kejadian penyakit kulit. OR 2,304 artinya pekerja yang penyediaan air bersihnya tidak memenuhi syarat berisiko 2,304 kali menderita penyakit kulit dibandingkan dengan pekerja yang penyediaan air bersihnya memenuhi syarat.

Menurut Chandra (2006) salah satu penyakit kulit yang disebarkan dan ditularkan melalui air adalah water washed mechanism, yaitu penyakit yang mekanisme penularan-nya berkaitan dengan kebersihan umum dan perorangan, seperti infeksi melalui kulit dan mata seperti scabies. Jika kondisi ini tidak segera mendapatkan penanganan maka dampak yang akan dirasakan oleh pekerja adalah menderita penyakit kulit yang sangat mengganggu, menimbulkan kesengsaraan, penderitaan, ketidakmampuan sampai kerugian ekonomi, sedangkan dampak bagi perusahaan adalah menurunnya produktifitas kerja.

Penilaian penyediaan air yang memenuhi syarat berdasarkan sumber air bersih yang digunakan, syarat secara fisik tidak berwarna, tidak berbau dan tidak berasa serta hasil pemeriksaan kualitas air bersih secara mikrobiologi dengan pengukuran Coliform dan E. coli. Karena air yang dikatakan sehat adalah air yang tidak mengandung mikroorganisme penyebab penyakit. Hasil pemeriksaan E.coli pada air bersih yang digunakan pekerja 45,2\% dinyatakan positif, sedangkan hasil pemeriksaan coliform $17,1 \%$ dinyatakan positif. Keberadaan E.coli dan Coliform ini menandakan bahwa air bersih telah tercemar. Total Coliform yang masih diperbolehkan menurut Permenkes RI No. 416/MENKES/PER/IX/1990 adalah 50/100 ml air untuk bukan perpipaan dan $10 / 100 \mathrm{ml}$ air untuk perpipaan. Pencemaran dapat terjadi saat pendistribusian air dari penampungan air (tower PTPN) ke rumah-rumah pekerja yang tinggal dilingkungan perumahan PTPN VII. Adanya kebocoran pipa pendistribusian dapat menjadi celah masuknya mikroorganisme. Begitupun dengan pekerja yang tinggal diluar komplek perumahan PTPN yang memperoleh air bersih dari PAM. Pekerja sebaiknya segera melaporkan kepada petugas saat terjadi kebocoran sehingga dapat segera ditangani untuk mencegah masuknya mikroorganisme ke dalam saluran air bersih. Pemeriksaan kualitas air bersih secara berkala juga diperlukan agar air bersih yang digunakan di PTPN VII Unit Usaha Way Berulu dapat senantiasa terpantau kualitasnya.

Pekerja yang mendapatkan air bersih dari sumur bor ataupun sumur gali, sebaiknya menampung air untuk keperluan sehari-hari dalam bak yang diberi penutup untuk menghindari jatuhnya kotoran kedalam air, sehingga kualitas air lebih terjaga. Bagi pekerja yang menggunakan air bersumber dari sungai, sebaiknya dilakukan peyaringan sederhana. Sungai dewasa ini sudah tidak dapat dikatakan bersih lagi. Adanya pengotoran baik dari kegiatan manusia maupun kegiatan industri telah mencemari air sungai. Perlakuan terhadap air sungai sebelum digunakan akan mengurangi risiko terjadinya penyakit yang disebarkan melalui air.

\section{Penggunaan APD}

Alat pelindung diri merupakan alat yang digunakan untuk melindungi diri dari bahaya kecelakaan ataupun penyakit. Hasil pada tabel 1 dapat dijelaskan bahwa $47,9 \%$ pekerja tidak menggunakan APD sedangkan yang menggunakan APD hanya $52,1 \%$. Hasil tersebut menunjukkan bahwa kesadaran pekerja dalam menggunakan alat perlindungan diri masih belum tinggi. Padahal APD merupakan alat yang dapat digunakan untuk perlindungan diri dari bahaya akibat kerja.

Tabel 2 menerangkan pada kelompok pekerja menderita penyakit kulit yang tidak menggunakan alat pelindung diri sebanyak 57,5\%. Pada kelompok pekerja tidak menderita penyakit kulit yang tidak menggunakan alat pelindung diri sebanyak $38,4 \%$. Uji statistik mendapatkan nilai $p=0,037<\alpha(0,050)$ dapat disimpulkan ada hubungan yang bermakna antara penggunaan alat pelindung diri dengan kejadian penyakit kulit. $\mathrm{OR}=2,177$ artinya pekerja yang tidak menggunakan APD berisiko 2,177 kali untuk menderita penyakit kulit akibat kerja dibandingkan dengan pekerja yang menggunakan APD.

Hasil diatas didukung oleh penelitian Erliana (2008) yang menunjukkan bahwa terdapat perbedaan proporsi antara pekerja yang menggunakan APD dengan pekerja yang tidak menggunakan APD.

Studi lain yang dilakukan Mausulli (2010) pada pekerja pengelolaan sampah juga menunjukkan hasil yang sama, dimana pekerja yang tidak menggunakan APD, mengalami dermatitis kontak iritan sebanyak 59,5\% sedangkan pekerja yang menggunakan APD, 
tidak ada yang mengalami dermatitis kontak iritan. Hasil penelitian ini juga sejalan dengan penelitian yang dilakukan oleh Husaini (2017) bahwa responden yang tidak menggunakan APD selama bekerja, berisiko dan berpeluang 1,500 kali lebih besar untuk menderita penyakit kulit akibat kerja.

Penelitian yang dilakukan di PTPN VII Unit Usaha Way Berulu ini mendapatkan hasil ada hubungan yang bermakna antara penggunaan APD dengan kejadian penyakit kulit. Kegiatan produksi di PTPN VII menggunakan bahan kimia sebagai campuran dalam proses koagulasi. Bahan tersebut dapat masuk melalui kulit dan mukosa secara akut dan secara kronis. Efek yang dirasakan berupa iritasi dan alergi dengan gejala gatal-gatal (saat pagi, siang, malam, ataupun sepanjang hari), muncul bintik-bintik merah/ bentol-bentol/ bula-bula yang berisi cairan bening ataupun nanah pada kulit permukaan tubuh, timbul ruam-ruam, kadang disertai demam. Agar terhindar dari penyakit kulit akibat bahan kimia yang dicampurkan, sebaiknya pekerja menggunakan masker, sarung tangan dan memakai sepatu but yang tidak licin sehingga kaki terlindungi dari siraman air yang bercampur dengan asam semut saat penggumpalan latek.

Tangan, badan dan kaki merupakan bagian tubuh yang paling sering terkena dermatitis kontak akibat kerja di perkebunan karet. Jenis APD yang relevan dengan pekerjaan yang kontak dengan karet di perkebunan yaitu sarung tangan, sepatu bot, masker dan pakaian pelindung.

Penggunaan APD diatur dalam Peraturan Menteri Tenaga Kerja dan Transmigrasi republik Indonesia No.PER.08/MEN/VII/2010 tentang Alat Pelindung Diri pasal 4 (1) poin d, APD wajid digunakan di tempat kerja dimana dilakukan usaha pertanian, perkebunan, pembukaan hutan, pengerjaan hutan, pengolahan kayu atau hasil hutan lainnya, peternakan, perikanan dan lapangan kesehatan. Dan pasal 5: Pengusaha atau Pengurus wajib mengumumkan secara tertulis dan memasang rambu-rambu

\section{DAFTAR PUSTAKA}

Adisesh A., Robinson E., Nicholson P.J., Sen D., Wilkinson M. (2013). UK Standards of Care for Occupational Contact Dermatitis and Occupatinal Contact Urticaria. British Journal of dermatology. 168: 1167-1175.

Ariawan, I. (1998). Besar dan Metode Sampel pada Penelitian Kesehatan. Depok: Fakultas Kesehatan Masyarakat, Universitas Indonesia. mengenai kewajiban penggunaan APD di tempat kerja.

Kejadian sakit yang dialami pekerja akan merugikan perusahaan. Ketidakhadiran pekerja karena sakit yang dialaminya, akan menurunkan produktifitas perusahan yang berimbas pada hasil produksi. Kondisi tersebut perlu disikapi dengan rencana tindak lanjut. Setiap perusahaan memiliki hasil olahan yang berbeda. PTPN VII Way Berulu telah menyediakan APD, namun masih terdapat pekerjanya yang tidak menggunakan APD tersebut dengan alasan ketidaknyamanan. Pada awal penggunaan, bisa jadi APD yang digunakan terasa tidak nyaman. Kesadaran tentang pentingnya penggunaan APD perlu ditanamkan kepada pekerja. Agar kesehatan kerja dapat dijaga dan ditingkatkan, pada awalnya perlu adanya pengawasan dari pihak perusahaan. Seiring waktu, karena sudah terbiasa menggunakan, pekerja akan menggunakannya dengan kesadaran masing-masing tanpa adanya paksaan. Standar Operasional Prosedur (SOP) diperlukan dalam rangka pengawasan bagi para pekerja demi meningkatkan kesehatannya.

\section{SIMPULAN}

Proporsi pekerja yang pernah menderita penyakit kulit sebelumnya adalah sebesar $29,5 \%$ dan yang tidak pernah menderita penyakit kulit sebelumnya sebesar 70,5\%. Sebesar $34,2 \%$ pekerja telah memiliki personal hygiene yang kurang baik dan $65,8 \%$ baik. Penyediaan air yang tidak memenuhi syarat kesehatan $48,6 \%$, sedangkan $51,4 \%$ memenuhi syarat. Sebanyak $88,4 \%$ pekerja tidak menggunakan APD dan $11,6 \%$ menggunakan APD.

Terdapat hubungan yang bermakna antara riwayat penyakit kulit sebelumnya, personal hygiene, penyediaan air bersih dan penggunaan APD dengan kejadian penyakit kulit akibat kerjadi PTPN VII Unit Usaha Way Berulu Kabupaten Pesawaran Tahun 2017.
Chandra, Budiman. (2006). Pengantar Kesehatan Lingkungan. Jakarta: EGC.

Erliana. (2008). Hubungan Karateristik Individu dan Penggunaan Alat Pelindung Diri dengan kejadian Dermatitis Kontak pada Pekerja Paving Block CV. F. Lhoksumawe. (Skripsi, Universitas Sumatera Utara).

Hilma, UD, Gozali, L. (2014). Faktor-Faktor yang Mempengaruhi Kejadian Skabies di 
Pondok Pesantren Mlangi Nogotirto Gamping Sleman Yogyakarta. JKKI, Vol.6, No.3, September-Desember 2014.

Hudyono, J. (2002). Dermatosis akibat kerja. Majalah Kedokteran Indonesia, 49(9), 16-23.

Husaini, Setyaningrum, Ratna., Saputra, Mama., (2017). Faktor Penyebab Penyakit Akibat Kerja pada Pekerja Las. Jurnal Media Kesehatan Masyarakat Indonesia (MKMI), Vol. 13, No. 1, Maret 2017. Tersedia http://journal.unhas.ac.id/index.php/mkmi/ article/view/1583

Isro'in, Laili. (2012). Personal Hygiene. Jakarta: Graha Ilmu.

Mausulli A. (2010). Faktor-Faktor Yang Berhubungan Kejadian Dermatitis Kontak Iritan Pada Pekerja Pengolahan Sampah di TPA Cipayung Kota Depok. (Skripsi, Univesitas Islam Negri, Jakarta).

Nelson JL and Mowad CM. (2010). Allergic contact dermatitis: Patch Testing Beyond the TRUE Test. The Journal of Clinical and Aesthetic Dermatology. Tersedia: http://www.ncbi.nlm.nih.gov/pmc/articles/ pmc2958195/

Nuraga, Wisnu, Fatma Lestari, Kurniawidjaya L. Meily. (2008). Faktor-faktor yang Mempengaruhi Kejadian Dermatitis Kontak pada Pekerja yang Terpajan
Dengan Bahan Kimia di Perusahaan Industri otomotif Kawasan Industri Cibitung Jawa Barat. Makara Kesehatan, Vol. 12, No. 2 Desember 2008, 63-67.

Pratiwi, Margareta., Eka. (2016). Hubungan Pemaiakan APD, Hygiene Perorangan dan Riwayat Penyakit dengan Penyakit Dermatitis Alergi Akibat Kerja di PT. PSUT Jambi Kabupaten Muaro Jambi Tahun 2016. Scientia Journal, Vol. 5 No. 22. Tersedia http://ejournal.unaja.ac.id/index.php/SCJ/arti cle/download/176/163

Rahma, Gresi Amarita., Setyaningsih, Yuliani., Jayanti, Siswi. (2017). Analisis Fakor Eksogen dan Endogen Terhadap Kejadian Dermatitis Akibat Kerja pada Pekerja Penyamakan Kulit PT. Adi Satria Abadi Piyungan, Bantul. Jurnal Kesehatan Masyarakat, Volume 5, Nomor 5, Oktober 2017 (ISSN:2356-3346). Tersedia: http://ejournal3.undip.ac.id/index.php/jkm

Stateschu L. (2011). Spitalul Clinic Deurgenta Clinic Dermatologie. Dutch: Universtatea de Medicina si Farmacie.

Usatine, R. P., \& Riojas, M. (2010). Diagnosis and management of contact dermatitis. Am Fam Physician, 82(3), 249-255.

Wasitaatmaja, Syarif M. (2011). Ilmu Penyakit Kulit dan Kelamin. Jakarta: FKUI. 